\title{
パラメータ励振回路に発生する各種の 非線形振動
}

京都大学大嶋 健 司

\section{1.まえがき}

第1图に示すような二つの可飽和鉄心を持つ变圧器 結合回路に衫け万各種の周期振動および概周期振勤に つて势察する。この回路は $1 / 2$ 調波振動発生する パラタータ励振回路*1 として知られているが，適当な 回路条件で，Zの回路に外力䦖波数 $\omega$ と有理数比 $m / n$ 在な骨波数成分在持つ $m / n$ 調波掁動が発生す



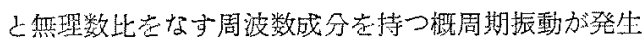
することもある。林氏はこの種の回路し生しる概䦖期 振動空位相空間に执いて解析し，振動の励起について

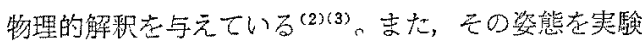
的に鈇察している(4)。Thomson 氏は磁気堌幅回路 における概周期振動について実験的考察を行ってい る(5)。この種の振動は可飽和リアクトルに声流进重盢 した場合の共振回路抢よび各種の非線形回路に执いて あ発生する場合がある ${ }^{(6)-(10)}$ ，てれらの周期振動およ び概周期振動の周波数成分について実駘的には考察さ

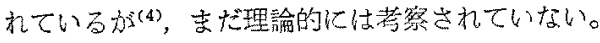

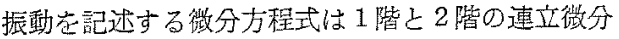
万程式となる。本椧文ではこの力程式の解を調波解析

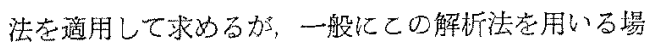

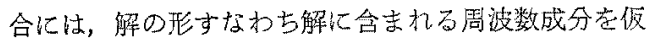

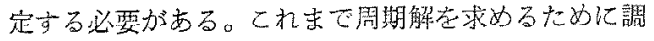
波招析法定用いる場合には，解の周波数成分として， 外方周波数，その㗬調波，分数調波なとの成分を仮定 して，これら周波数成分の振幅を洲定していた。すな わち，解の主要成分の周波数在㤩ず仮定して，その振

Nonlinear Oscillations in a Parametric Excitation Circuit. By Kenji Ohshima, Member (Department of Electrical Engineering, Kyoto University). 大㣎做司：正員，家都大学工学部

昭 $51-11$

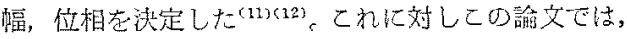
まず振動の主要周波数成分として外力周波数 $\omega$ およひ

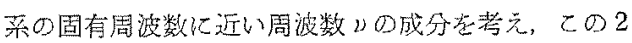
成分上りなる解索第 1 次近似解上子る。乙こに周波数 レは系のパシメータのみでなく振勤の振幅化委依存す るものて，その值は䛺波解析法定用いて決定さ礼る。 次に非線形特性により解には $\omega$ および山以外の周波数

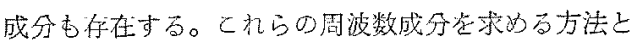
して，乙の近似解索无の微分与程式に代入し，繰返し

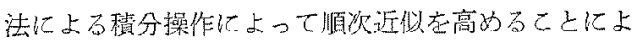
り主要成分の周波数党定める方法を提案した。これら ○周波数成分の振幅求上び周汥数を調波解析法苯用い て法定することにより，周期解の子でなく概周期解も

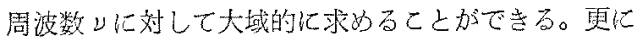
この解析万法の学当性害駼によって確かかる。

この解析方法は, 各種の非線形回路に抄ける振動の

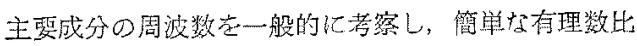
$m / n$ の周波数成分在持つ周期振動の子でなく，概周期 振動を一般的に解析する場合に適用することができ $3^{(13)-(17)}$ 。

\section{2. 基碟方程式}

第 1 图の記号点用いると次の回路力程式在得る。

$$
\left.\begin{array}{l}
n \frac{d}{d t}\left(\phi_{1}+\phi_{2}\right)+R_{1} i_{1}=E \sin \omega t \\
n \frac{d}{d t}\left(\phi_{1}-\phi_{2}\right)+\frac{1}{C} \int i_{C} d t=0 \\
R_{2} i_{R}=\frac{1}{C} \int i_{C} d t, \quad i_{2}=i_{R}+i_{C}
\end{array}\right\}
$$

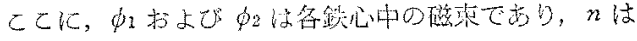

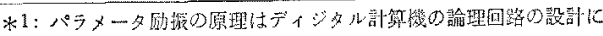
应用されている(1)。 


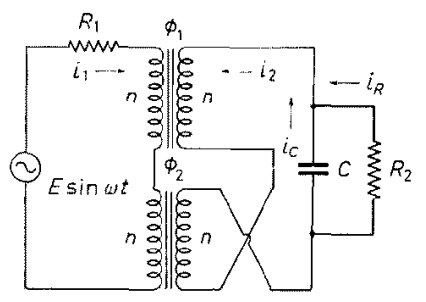

第 1 図パラメー夕励娠回路

Fig. 1. Parametric excitation circuit.

各コイルの巻数で䓃る。二つの可慨和リアクトルは同 じ磁化特性考持つむの上し，次のよう仮定する。

$c \phi_{1}^{3}=n i_{1}+n i_{2}, \quad c \phi_{2}^{3}=n i_{1}-n i_{2} \ldots(2)$

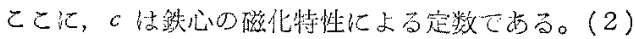

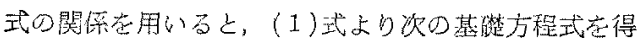
る。

$$
\left.\begin{array}{l}
\frac{d a}{d \tau}+\frac{1}{8} k_{1}\left(a^{2}+3 b^{2}\right) a=B \sin \tau \\
\frac{d^{2} b}{d \tau^{2}}+\frac{k_{2}}{m} \frac{d b}{d \tau}+\frac{1}{8 m}\left(3 a^{2}+b^{2}\right) b=0
\end{array}\right\}
$$

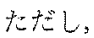

$$
\left.\begin{array}{l}
a=v_{1}+v_{2}, \quad b=v_{1}-v_{2}, \quad i_{j}=I_{n} u_{j} \\
\phi_{j}=\Phi_{n} v_{j} \quad(j=1,2), \quad C=C_{n} m \\
n \omega^{2} C_{n} \Phi_{n}=I_{n}, \quad c \Phi_{n}^{3}=n I_{n} \\
k_{1}=\omega C_{n} R_{1}, \quad k_{2}=1 /\left(\omega C_{n} R_{2}\right) \\
B=E /\left(n \omega \Phi_{n}\right)
\end{array}\right)
$$

\section{3. 定常解の仮定 ${ }^{(13) \sim(16)}$}

$$
\begin{aligned}
& k_{1}=0 \text { 㕲上び } k_{2}=0 \text { Ф揚合，(3)式は } \\
& \quad \frac{d a}{d \tau}=B \sin \tau, \frac{d^{2} b}{d \tau^{2}}+\frac{1}{8 m}\left(3 a^{2}+b^{2}\right) b=0
\end{aligned}
$$

となる。佂共振回路の固有周波数とすると， $\nu_{0}^{2}$ は

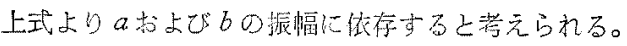

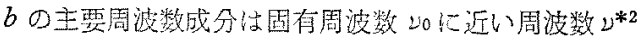

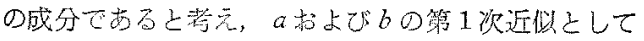
次式を仮等士者。

$$
a=A_{1} \cos \tau, b=B_{\nu} \sin \left(\nu \tau+\beta_{\nu}\right)
$$

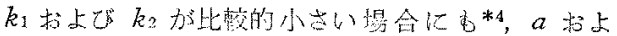

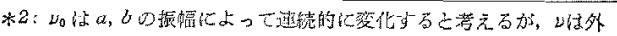

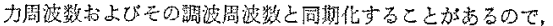
$\nu_{0}$ 乙区別して考无原。

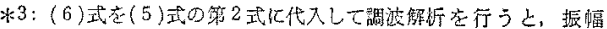

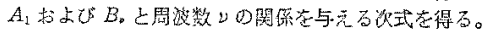
$\nu \neq 1: \nu^{2}=(3 / 32 m)\left(2 A_{1}^{2}+B_{*}^{2}\right)$

び bの第 1 次近似しして(6)式党仮定する（3)式在 書古直す

$$
\left.\begin{array}{l}
\frac{d a}{d \tau}=B \sin \tau-\frac{1}{8} k_{1}\left(a^{2}+3 b^{2}\right) a \\
\frac{d^{2} b}{d \tau^{2}}=-\frac{k_{2}}{m} \frac{d b}{d \tau}-\frac{1}{8 m}\left(3 a^{2}+b^{2}\right) b
\end{array}\right\}
$$

となる。(6)式本（7)式の右包に代入し，aおよび 䣇めると

$$
\begin{aligned}
a= & -B \cos \tau \\
& -\frac{1}{8} k_{1}\left[\left(\frac{3}{4} A_{1}{ }^{2}+\frac{3}{2} B_{\nu}{ }^{2}\right) A_{1} \sin \tau\right. \\
& -\frac{3}{4(1-2 \nu)} A_{1} B_{\nu}{ }^{2} \sin \left\{(1-2 \nu) \tau-2 \beta_{\nu}\right\} \\
& -\frac{3}{4(1+2 \nu)} A_{1} B_{\nu}{ }^{2} \sin \left\{(1+2 \nu) \tau+2 \beta_{\nu}\right\} \\
& \left.+\frac{1}{12} A_{1}{ }^{3} \sin 3 \tau\right]+A_{0} \\
b= & \frac{k_{2}}{m} \frac{1}{\nu} B_{\nu} \cos \left(\nu \tau+\beta_{\nu}\right)+\frac{1}{8 m} \\
& \times\left[\frac{1}{\nu^{2}}\left(\frac{3}{2} A_{1}{ }^{2}+\frac{3}{4} B_{\nu}{ }^{2}\right) B_{\nu} \sin \left(\nu \tau+\beta_{\nu}\right\}\right. \\
& -\frac{3}{4(2-\nu)^{2}} A_{1}{ }^{2} B_{\nu} \sin \{(2-\nu) \tau \\
& -\frac{3}{4(2+\nu)^{2}} A_{1}{ }^{2} B_{\nu} \sin \left\{(2+\nu) \tau-\beta_{\nu}\right\} \\
& \left.\left.-\frac{1}{36 \nu^{2}} B_{\nu}{ }^{3} \sin \left(3 \nu \tau+3 \beta_{\nu}\right)\right]+B_{0}+\beta_{\nu}\right\}
\end{aligned}
$$

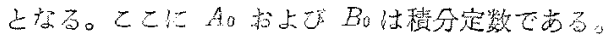

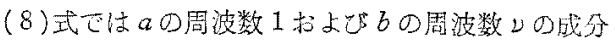
以外の周波数成分力現われる。しれらの周波数成分の

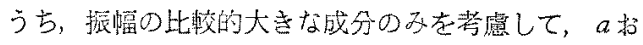
よび $b$ の第 2 次近以式定次の上うに仮定寸る。

$$
\begin{aligned}
a= & A_{1} \sin \left(\tau+\alpha_{1}\right) \\
& +A_{1-2 \nu} \sin \left\{(1-2 \nu) \tau+\alpha_{1-2 \nu}\right\} \\
b= & B_{\nu} \sin \left(\nu \tau+\beta_{\nu}\right) \\
& +B_{2-\nu} \sin \left\{(2-\nu) \tau+\beta_{2-\nu}\right\}
\end{aligned}
$$

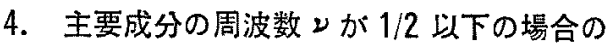 定常解の一般的考察*5}

ここでは，周波数 $\nu$ か $1 / 2$ 以下の場合に刘し周期解

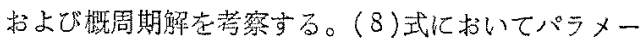
タ长あるい怯波数しの值いかんによっては影著に 現われる周活数成分向古り，十分小なる周波数成分も

\footnotetext{
*5：ここで，周波数りが より小さい坦合の定常解について考察

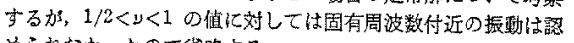
るら却なかったので省路する。
} 
第 1 䒾（10)式を(3)式に代入して 得られる周波数

Table 1. Frequencies obtained by inserting Eq. (10) into (3).

\begin{tabular}{|c|c|c|c|}
\hline 主要成分周波数 p & $\nu=1 / 3$ & $\nu=1 / 2$ & $\nu \neq 1 / 3, \nu \neq 1 / 2$ \\
\hline 波数 & $1,3-6 y$ & 1. $3-4 \nu, 4 \nu-1$ & 1 \\
\hline $\begin{array}{l}1-2 \nu \text { 箱しくな } \\
\text { 万周波数 }\end{array}$ & $1-2 \nu, 4 \nu-1$ & $1-2 \nu, 3-6 v$ & $1-2 y$ \\
\hline 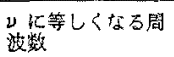 & $\nu, 2-5 \nu$ & $\nu, 2-3 \nu, 5 \nu-2$ & $\nu$ \\
\hline
\end{tabular}

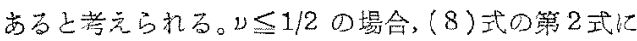

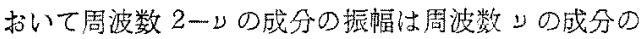
振幅と比較して十分小さいので*6, 括上び $b$ 第 2 次近似式走次の上うに仅定する*7。

$$
\begin{aligned}
a= & A_{1} \sin \left(\tau+\alpha_{1}\right) \\
& +A_{1-2 \nu} \sin \left\{(1-2 \nu) \tau+\alpha_{1-2 \nu}\right\} \\
b= & B_{\nu} \sin \left(\nu \tau+\beta_{\nu}\right)
\end{aligned}
$$

(10)式芯次のように菁き啚すことがでる。

$$
\left.\begin{array}{rl}
a= & x_{1} \sin \tau+y_{1} \cos \tau \\
& +x_{1-2 \nu} \sin (1-2 \nu) \tau+y_{1-z_{\nu}} \cos (1-2 \nu) \tau \\
b= & x_{r} \sin \nu \tau+y_{\nu} \cos \nu \tau
\end{array}\right\}
$$

ここK.

$$
\begin{gathered}
x_{s}=A_{s} \cos \alpha_{s}, \quad y_{s}=A_{s} \sin \alpha_{s} \\
(s=1, \quad 1-2 \nu) \\
x_{\nu}=B_{\nu} \cos \beta_{\nu}, \quad y_{\nu}=B_{\nu} \sin \beta_{\nu}
\end{gathered}
$$

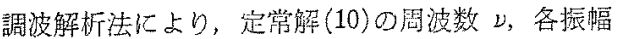
およむ゙位相角を決定するために，(10)式を(3)式の第

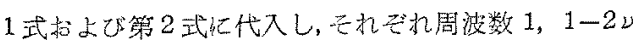

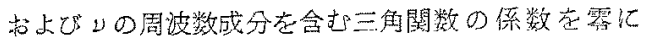
等しい己監々。(10)式老(3)式代入して得られる式

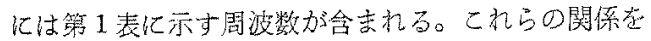
考慮して調波解析苍行う。

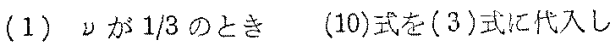
七調波解析在行方上次式走得召。

$$
\begin{aligned}
& X_{1}+(1 / 32) k_{1} A_{1-2 \nu}{ }^{3} \cos \varphi_{1}=0 \\
& Y_{1}+(1 / 32) k_{1} A_{1-2 \nu}{ }^{3} \sin \varphi_{1}=0 \\
& X_{1-2 \nu}+(3 / 32) k_{1} A_{1-2 \nu}\left(A_{1} A_{1-2 \nu} \cos \varphi_{1}\right. \\
& \left.\quad-B_{\nu}{ }^{2} \cos \varphi_{2}\right)=0 \\
& Y_{1-2_{\nu}}+(3 / 32) k_{1} A_{1-2 \nu}\left(A_{1} A_{1-2 \nu} \sin \varphi_{1}\right.
\end{aligned}
$$

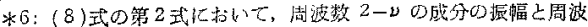

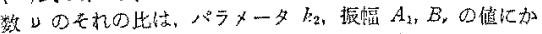
加和ず， $\left\{(3 / 4) /(2-2)^{2}\right\} /\left\{(3 / 2) / \nu^{2}\right\}$ より小で古り，これ依

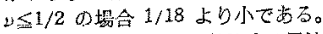

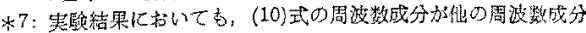

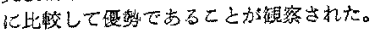

$$
\left.+B_{\nu}^{2} \sin \varphi_{2}\right)=0
$$

$X_{\nu}+(9 / 64 m) A_{1-2 \nu}{ }^{2} B_{\nu} \sin \varphi_{2}=0$

$Y_{\nu}+(9 / 64 m) A_{1-2 \nu}{ }^{2} B_{\nu} \cos \varphi_{2}=0$

¿こK,

$$
\begin{aligned}
& \varphi_{1}=-\alpha_{1}+3 \alpha_{1-2 \nu} \\
& \varphi_{2}=-2\left(\alpha_{1-2 \nu}-\beta_{\nu}\right)
\end{aligned}
$$

$$
\begin{aligned}
X_{1}= & -(1 / 8) k_{1}\left[P_{1} A_{1}-(3 / 4) A_{1-g_{\nu}} B_{\nu}{ }^{2}\right. \\
& \left.\times \cos \left(\alpha_{1}-\varphi\right)\right]+B \cos \alpha_{1} \\
Y_{1}= & -A_{1}-(3 / 32) k_{1} A_{1-2 \nu} B_{\nu}{ }^{2} \sin \left(\alpha_{1}-\varphi\right) \\
+ & B \sin \alpha_{1} \\
X_{1-2 \nu}= & -(1 / 8) k_{1}\left[P_{2} A_{1-2 \nu}\right. \\
& \left.-(3 / 4) A_{1} B_{\nu}{ }^{2} \cos \left(\alpha_{1}-\varphi\right)\right] \\
Y_{1-2 \nu}= & -(1-2 \nu) A_{1-2 \nu} \\
& +(3 / 32) k_{1} A_{1} B_{\nu}{ }^{2} \sin \left(\alpha_{1}-\varphi\right) \\
X_{\nu}= & -(1 / 2 m) k_{2} B_{\nu} \\
& +(3 / 32 m \nu) A_{1} A_{1-2 \nu} B_{\nu} \sin \left(\alpha_{1}-\varphi\right) \\
Y_{\nu}= & (1 / 16 m \nu)\left(P_{3} B_{\nu}\right. \\
& \left.-(3 / 2) A_{1} A_{1-2 \nu} B_{\nu} \cos \left(\alpha_{1}-\varphi\right)\right] \\
P_{1}= & (3 / 4) A_{1}{ }^{2}+(3 / 2)\left(A_{1-2 \nu}{ }^{2}+B_{\nu}{ }^{2}\right) \\
P_{2}= & (3 / 4) A_{1-2 \nu}{ }^{2}+(3 / 2)\left(A_{1}{ }^{2}+B_{\nu}{ }^{2}\right) \\
P_{3}= & (3 / 4) B_{\nu}{ }^{2}+(3 / 2)\left(A_{1}{ }^{2}+A_{1-2 \nu}{ }^{2}\right) \\
& -8 m \nu^{2} \\
\varphi= & \alpha_{1-2 \nu}+2 \beta_{\nu}
\end{aligned}
$$

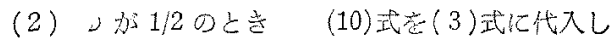
て誠波解析を行う上次式学得召。

$$
\begin{aligned}
& X_{1}+(3 / 32) k_{1} A_{1-2 v}\left(2 A_{1} A_{1-2 \nu} \cos \varphi_{3}\right. \\
& \quad-B_{\nu}{ }^{2} \cos \varphi_{4}=0 \\
& Y_{1}+(3 / 32) k_{1} A_{1-2 \nu} B_{\nu}{ }^{2} \sin \varphi_{4}=0 \\
& X_{1-2 \nu}+(3 / 32) k_{1} A_{1-2 \nu}{ }^{3} \cos \varphi_{3}=0 \\
& X_{\nu}-(3 / 16 m \nu) A_{1} A_{1-2 \nu} B_{\nu} \sin \varphi_{4}=0 \\
& Y_{\nu}-(3 / 16 m \nu) A_{1} A_{1-2 \nu} B_{\nu} \cos \varphi_{4}=0 \\
& \varphi_{3}=2 \alpha_{1-2 \nu}=\pi, \quad \varphi_{4}=\alpha_{1}+\alpha_{1-2 \nu}-2 \beta_{\nu}
\end{aligned}
$$

ただし，て彷の式には(14)武の記昂老用いた。

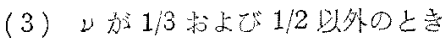

(10)式在

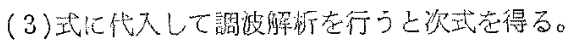

$$
\left.\begin{array}{l}
d A_{1} / d \tau=X_{1}, \quad 0=Y_{1}, \quad 0=X_{1-2_{\nu}} \\
0=Y_{1-2 \nu}, \quad d B_{\nu} / d \tau=X_{\nu}, \quad B_{\nu} d \beta_{\nu} / d \tau=Y_{\nu}
\end{array}\right\}
$$

ただし，て能の式には(14)式の記昂在用いた。また 定常解に対しては各掁幅社よび位相角は一定值をよる 
が，欲に定常解の安定性を吟味するために，てれらの

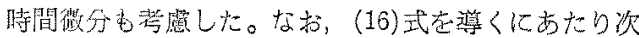
○坂定を設けた。

（i）（11)式の振幅 $x_{v}$ 抢よび $y_{v}$ 《时間の経過上 共行継や加変化するものとし，また $k_{2}$ は小さい量 とする。徉って $d^{2} x_{v} / d \tau^{2}, d^{2} y_{v} / d \tau^{2}, k_{2} d x_{v} / d \tau$ およ

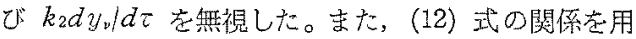

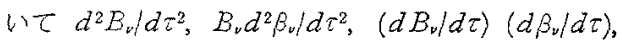
$B_{v}\left(d \beta_{v} / d \tau\right)^{2}, k_{2} d B_{\nu} / d \tau$ 拈よび $k_{2} B_{\nu} d \beta_{v} / d \tau$ を無視 L犬。

（ii）莫に $k_{1}$ は小さい量とする。徒って，第 2 次 近似解(11) の振幅 $x_{1}, x_{1-2 v}$ 拉よび $y_{1-2 v}$ 法第 1 次近 似解 (6)の掁幅 $A_{1}\left(=y_{1}\right)$ と比較して小さい。また。各 振愠は眭間の経過上共に，楥や加江変化する屯の上す る。從って $d x_{1} / d \tau, d x_{1-2 v} / d \tau$ 朽よび $d y_{1-2 v} / d \tau$ を 無視した。また(12)式の関係在用いて $A_{1} d \alpha_{1} / d \tau$, $d A_{1-2 v} / d \tau$ 抢上び $A_{1-2 v} d \alpha_{1-2 v} / d \tau$ を無視した。な

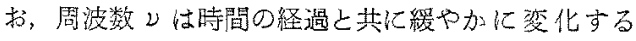
ものとし，その时閭微分を無視しだ。

〈4.1〉周期解 周波数 場合，(3)式の周期解は(10)式で示さ机る。菜のパラ メータ $B, k_{1}, k_{2}$ 就よび $m$ て適当に与光ると，(13)式 あるいは(15)式上り周期解(10) ○振幅 $A_{1}, A_{1-2}, B_{v}$, 位租角 $\alpha_{1}, \alpha_{1-2 \nu}$ 拉よび $\beta_{v}$ がずべて求まる。周波数 $\nu$ がある一定の值 (1/3あるいは 1/2) 亿刘し，解(10)が 柔のバラメータ $B, k_{1}, k_{2}$ 朽よび $m$ の古る範国内で求

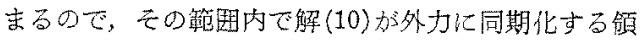
域のあるこ亡がわかる。

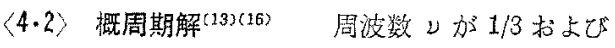
1/2 以外の場合，(3) 式の䡒周期解は(10)式で示され る。(10)式老(3)式似代入し調波解析在行って(16)式 を得た。(16)式老珰き換无ると

$$
\left.\begin{array}{l}
d A_{1} / d \tau=X_{1}, \quad 0=Y_{1} / A_{1}, \quad 0=X_{1-2 \nu} \\
0=Y_{1-2 \nu} / A_{1-2 \nu}, \quad d B_{\nu} / d \tau=X_{\nu} \\
d \varphi / d \tau=Y_{1-2 \nu} / A_{1-2 \nu}+2 Y_{\nu} / B_{\nu} \\
\varphi=\alpha_{1-2 \nu}+2 \beta_{\nu}
\end{array}\right\}
$$

となる。定常状態では，(17)式代おいて $d A_{1} / d \tau=0$, $d B_{v} / d \tau=0, d \varphi / d \tau=0$ となる。乙とて振幅 $A_{1}, A_{1-2 v}$,

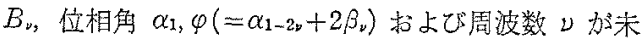
知数である。従って，系のパラメータ $B, k_{1}, k_{2}$ および $m$ 在適当化与元ると，(17)式上り振愊 $A_{1}, A_{1-2 v}, B_{v}$, 位相角 $\alpha_{2}, \varphi$, 周波数 $\nu$ は定まる。 $\varphi\left(=\alpha_{1-2 v}+2 \beta_{v}\right)$ 加 定まってす， $\alpha_{1-2 n}, \beta_{x}$ は定末らず，任恋の值定取り得 る。パラメータ $B, k_{1}, k_{2}$ 古るいは $m$ 走变元る上，そ

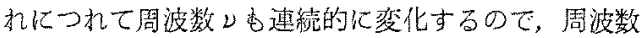
レは無理数となるととがある。良って，てのときの解

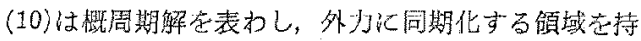
たないことが加かる。数值例奆第 5 章化示苛。

\section{5. 定常解の安定性 ( $\boldsymbol{\nu} 1 / 2$ の場合)}

$\langle 5 \cdot 1\rangle$ 周期解の安定性 ${ }^{\langle 3\rangle}$ 周波数 $\nu$ か $1 / 3$ ある いは $1 / 2$ の哠合，（3）式の周期解は (10) 式で示され る。周期解の安定性を吟味するため化，乙の周期解を $a_{0}(\tau)$ 拉よび $b_{0}(\tau)$ て表和し，乙机加らの微小变分 $\xi(\tau)$ 扰よひ $\eta(\tau)$ を考える。変分

$$
a=a_{0}+\xi, b=b_{0}+\eta
$$

によって定義する。(18)式を(3)式に代入し， $d \eta / d \tau$ $=\zeta$ 之置いて次の变分方程式を得る。

$$
\left.\begin{array}{l}
\frac{d \xi}{d \tau}=-\frac{3}{8} k_{1}\left[\left(a_{0}{ }^{2}+b_{0}{ }^{2}\right) \xi+2 a_{0} b_{0} \eta\right] \\
\frac{d \eta}{d \tau}=\zeta \\
\frac{d \zeta}{d \tau}=-\frac{3}{8 m}\left[2 a_{0} b_{0} \xi+\left(a_{0}{ }^{2}+b_{0}{ }^{2}\right) \eta\right]-\frac{k_{2}}{m} \zeta
\end{array}\right\}
$$

(19)式は時間の周期関数を佰数付持つ連立線形微分 方程式であり，その理論によれば

$$
\left.\begin{array}{l}
\xi^{(i)}(\tau+L)=m_{i} \xi^{(i)}(\tau) \\
\eta^{(i)}(\tau+L)=m_{i} \eta^{(i)}(\tau) \\
\xi^{(i)}(\tau+L)=m_{i} \zeta^{(i)}(\tau)
\end{array}\right)
$$

なる関倸を満たす 3 組の独立な基本解を持つ。ここに $m_{i}$ 就特性乘数之称する定数で，(19) 式の特性方程式 の根として得られる ${ }^{(18)}$ 。(19)式の一般解は線形微分方 程式の性質により独立な 3 組の基本解を用いて

$$
\begin{aligned}
& \xi(\tau)=c_{1} \xi^{(1)}(\tau)+c_{2} \xi^{(2)}(\tau)+c_{3} \xi^{(3)}(\tau) \\
& \eta(\tau)=c_{1} \eta^{(1)}(\tau)+c_{2} \eta^{(2)}(\tau)+c_{3} \eta^{(3)}(\tau) \\
& \zeta(\tau)=c_{1} \xi^{(1)}(\tau)+c_{2} \zeta^{(2)}(\tau)+c_{3} \zeta^{(3)}(\tau)
\end{aligned}
$$

と表される。ここに，c1, $c_{2}$ および $c_{3}$ 仕任意定数です る。従って, 特性棌数 $m_{i}, \quad(i=1 \sim 3)$ の絶対值がつでむ1より大きいとき，(19)式の解(21)は時間の経 過之共に発散して周期解(10) は不安定となる。また特 性乗数 $m_{i}$ の絶対值がすべて1より小ならば，解 (21)

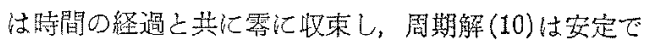
西る。

$\langle 5 \cdot 2\rangle$ 概周期解の安定性 ${ }^{(13\rangle}$ 既比〈4.2〉節で述 ベたように，周波数りが $1 / 3$ 杉よび $1 / 2$ などの簡学な 有理数比以外の場合，(3)式の解 (10)は概周期解之な り，概周期解(10)0各振幅，位相角拈よ゙び周波数は （17）式で記述さ机る。以下の式の表思簡监にするた 
わに，(17)式の記号を次のように觜き㛟える。

$\left(\begin{array}{c}A_{1} \\ B_{\nu} \\ \varphi \\ A_{1-2 v} \\ \alpha_{1} \\ \nu\end{array}\right)=\left(\begin{array}{c}x_{1} \\ x_{2} \\ x_{3} \\ x_{1} \\ x_{5} \\ x_{6}\end{array}\right),\left(\begin{array}{c}X_{1} \\ X_{\nu} \\ Y_{1-Z_{\nu}} / A_{1-z_{\nu}}+2 Y_{\nu} / B_{\nu} \\ X_{1-2_{\nu}} \\ Y_{1} / A_{1} \\ Y_{1-2_{\nu}} / A_{1-2, \nu}\end{array}\right)=\left(\begin{array}{c}X_{1} \\ X_{2} \\ X_{3} \\ X_{4} \\ X_{5} \\ X_{6}\end{array}\right)$

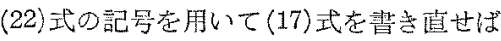

$$
\left.\begin{array}{l}
\frac{d x_{1}}{d \tau}=X_{1}, \quad \frac{d x_{2}}{d \tau}=X_{2}, \quad \frac{d x_{3}}{d \tau}=X_{3} \\
0=X_{4}, \quad 0=X_{5}, \quad 0=X_{6}
\end{array}\right)
$$

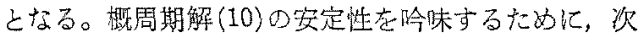
式で定義される各振幅，值相解抢よび周波数の定常值 $x_{i 0}(i=1 \sim 6)$ 加らの变分 $\xi_{i}$ 在考无尚。

$$
x_{i}=x_{i 0}+\xi_{i}(i=1 \sim 6)
$$

(24)式贲(23)式代代入して

$$
\begin{aligned}
& d \xi_{1} / d \tau=a_{11} \xi_{1}+a_{12} \xi_{2}+\cdots+a_{16} \xi_{6} \\
& d \xi_{2} / d \tau=a_{21} \xi_{1}+a_{22} \xi_{2}+\cdots+a_{26} \xi_{6} \\
& d \xi_{3} / d \tau=a_{31} \xi_{1}+a_{32} \xi_{2}+\cdots+a_{36} \xi_{6} \\
& 0=a_{41} \xi_{1}+a_{42} \xi_{2}+\cdots+a_{46} \xi_{6} \\
& 0=a_{51} \xi_{1}+a_{52} \xi_{2}+\cdots+a_{56} \xi_{6} \\
& 0=a_{61} \xi_{1}+a_{62} \xi_{2}+\cdots+a_{66} \xi_{6}
\end{aligned}
$$

なる变分方程式を得る。ここに $a_{i j}(i, j=1 \sim 6)$ は $x_{i}$ $=x_{i 0}(i=1 \sim 6)$ に打ける $\partial X_{i} / \partial x_{j}$ である。

$$
\xi_{i}=C_{i} e^{\lambda^{\tau}}(i=1 \sim 6)
$$

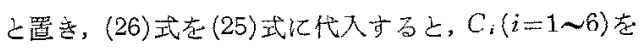
定める次式を得る。

$$
\left(\begin{array}{cccccc}
a_{11}-\lambda & a_{12} & a_{13} & a_{14} & a_{15} & a_{16} \\
a_{21} & a_{22}-\lambda & a_{23} & a_{24} & a_{25} & a_{26} \\
a_{31} & a_{32} & a_{33}-\lambda & a_{34} & a_{35} & a_{36} \\
a_{41} & a_{42} & a_{43} & a_{44} & a_{45} & a_{46} \\
a_{51} & a_{52} & a_{53} & a_{54} & a_{55} & a_{56} \\
a_{61} & a_{62} & a_{63} & a_{64} & a_{65} & a_{66}
\end{array}\right)\left(\begin{array}{l}
C_{1} \\
c_{2} \\
C_{3} \\
C_{4} \\
C_{5} \\
C_{6}
\end{array}\right)=0
$$

(27) 式が $C_{i}=0(i=1 \sim 6)$ У外の解芫持つためには， $\lambda$ 力s特性方程式

$$
\left(\begin{array}{cccccc}
a_{11}-\lambda & a_{12} & a_{13} & a_{14} & a_{15} & a_{16} \\
a_{21} & a_{22}-\lambda & a_{23} & a_{24} & a_{25} & a_{26} \\
a_{31} & a_{32} & a_{33}-\lambda & a_{34} & a_{35} & a_{36} \\
a_{11} & a_{42} & a_{43} & a_{44} & a_{45} & a_{46} \\
a_{51} & a_{52} & a_{53} & a_{54} & a_{55} & a_{56} \\
a_{61} & a_{62} & a_{63} & a_{64} & a_{65} & a_{66}
\end{array}\right)=0
$$

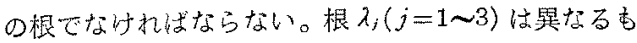

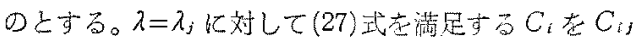
で表わせぜ, $\xi_{i j}=C_{i j} \ell_{j} \tau(i=1 \sim 6),(j=1 \sim 3)$ が(25) 式の3 組の解となる。隹って，(25)式の一般解は

$$
\xi_{i}=C_{i 1} e^{\lambda_{1} \tau}+C_{i 2} e^{\lambda_{2}{ }^{2}}+C_{i 3} e^{\lambda_{3} \tau}(i=1 \sim 6)
$$

ぐある。しこに(27)式より $C_{1 j}: C_{2 j}: \cdots \cdots: C_{6 j}$ の比

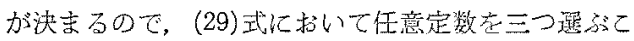
とができる。(29)式より根 $\lambda_{j}(j=1 \sim 3)$ の实数部がす べて鱼ならば，変分 $\xi_{i}(i=1 \sim 6)$ は特間の経過と共に 露に収束し，概周期解(10)は冬振幅 $A_{1}, A_{1-2}, B_{v}$, 位 相在 $\alpha_{1}, \varphi\left(=\alpha_{1-2 \nu}+2 \beta_{\nu}\right)$ 书よで周波数 $\nu$ K関して安 定である。既に〈4.2〉節で述べたように概周期解 (10) の尔振幅，位相角执よび周波数な記述寸る(17)式は， 位相角については $\alpha_{1}$ 抢よび $\varphi$ によって表加さ扎るの で，位相角 $\alpha_{1-2 y}$ 扣よび $\beta_{\nu}$ 级概周期解とは独立任 意の值をとることができる。

\section{数值例}

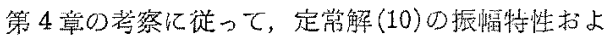
び周波数特性定 (13)，(15) 扎よび(17)式より求め，そ

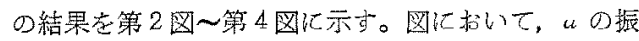
幅はbが振動している籍開でのみ示した。籁 5 草の考

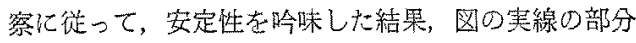
で安定であり，破線の部分で不安定でする。な拉，周

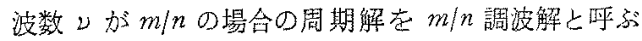
とと汇する。第 4 图0＼cjkstart概周期解(10)0 周波数山隹，パ ラメータ $B$ 在変化寸るとそ扎につれて連続的に变化 する。

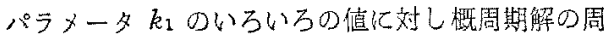
波数特性を求め，その結果を第 5 図に示す。第 5 章の 若察に従って安定性を吟味した結果，図の奏線の部分 で安定であり，破線の部分で不安定でる。

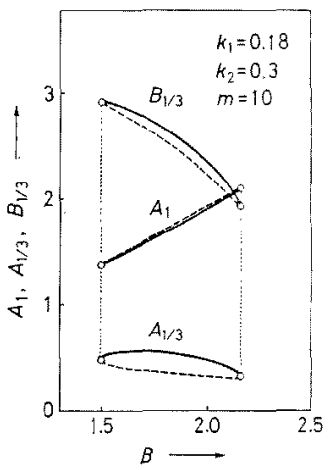

第 2 图 $1 / 3$ 調波振動の振幅特性

Fig. 2. Amplitude characteristic of the 1/3-harmonic oscillation. 


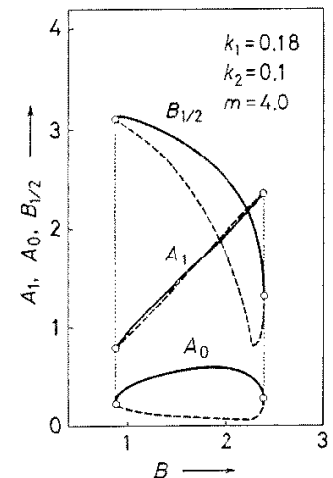

第 3 图 $1 / 2$ 調波振陲の振 幅特性

Fig. 3. Amplitude characteristic of the 1/2-harmonic oscillation.

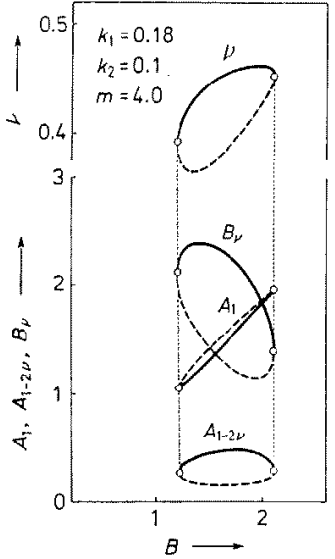

第 4 図 周波数 概周期振動の振幅特性叔上び周波数特性 Fig. 4. Amplitude characteristic and frequency characteristic of the almost periodic oscillation whose frequency $\nu$ lies between $1 / 3$ and $1 / 2$.



第 5 圆周波数 $\nu か 1 / 3 亡 1 / 2 の$ 間の概周期振既の周波数特性

Fig. 5. Frequency characteristic of the almost periodic oscillation whose frequency $\nu$ lies between $1 / 3$ and $1 / 2$.
周波烧りが 1/2より大さい場合の周期解および概周 期解も符 4 覃朽上び第 5 章上同様の考察を行って解析 することができるが，てれらの定常解についてとこで は筸略する。

\section{6. 実験的考察 $[13]$}

実験回路を符 6 図に示す。実験に用いたリアクトル の特性は，実験結果を解析結果と比較するために3 次 特性に近つけた。をのためには跌心化空げきを設けた リアクトルと䣰げきのないリアクトルを直列に接続し

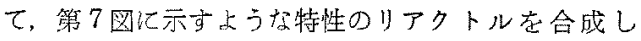
$た^{(7)}$ 。電源雪王の任意の位相において振動を闒始させ るために，逆並列に接続した SCR を用いて回路を閉 じるようにした。初期条体として，2次可路閉路時の

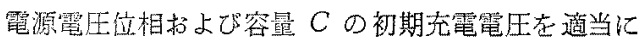
与えると $L C$ 共振回路にいろいるの振動が発生する。

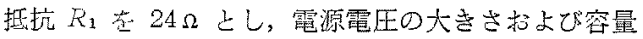

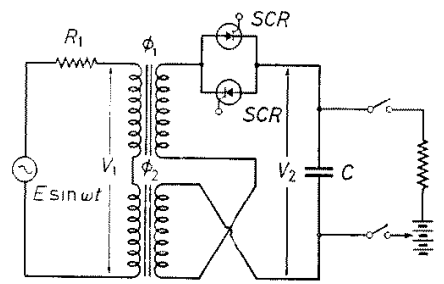

第 6 図笑験回路

Fig. 6. Experimental circuit.
$C$ 变变て各振勒の発生領域を求めた。実駼結果を第

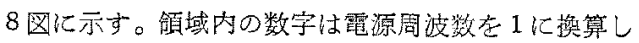
た㘯合の $L C$ 共振回路に打ける振動の主婜成分の周 波数レである。第 8 图の点線の斜鼣で示した領域ては 概周期振動が発告し，その平均周波数が電源周波数の $1 / 3$ と $1 / 2$ の閐変化するものと, 1 と $3 / 2$ の間に变 化するあのなどがする第 8 图において，おおむ榕 量 Cを小さくすると共振回路におりる振動の固有周 波数は高くなり，また電源電田の振幅孛大きくするに つれて振動磁束の平均值は大きくなり, リアクトルの 等価的インダクタンスが小さくなるのて固有周波数が


(1): 空げをを有しないリアクト

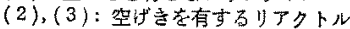

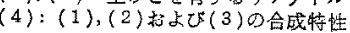

第 7 国 3 次㟫に近似したリアクトル ○特性

Fig. 7. Combined characteristic approximated to a cubic curve. 


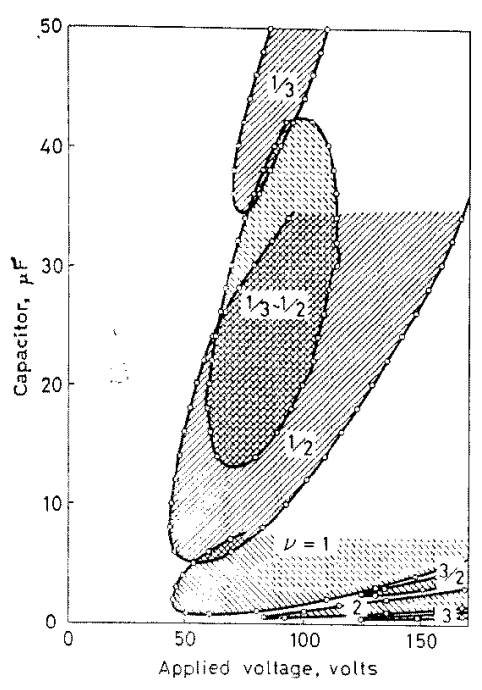

第 8 图振動発坐領域

Fig. 8. Regions in which different types of oscillation are sustained.



第 9 図 $1 / 3$ 調波振動の 振幅特性

Fig. 9. Amplitude characteristic of the $1 / 3$-harmonic oscillation.

高くなると教えられる。

第7図に示したリアクトルの特性は，麗死 $E \sin \omega t$ の振幅 $E$ と電流の波高倠 $I$ の関係で示すと

$$
I=1.53 E^{3} \times 10^{-6}(\mathrm{~A})
$$

で表わされる。電源周波数は $60 \mathrm{~Hz}$ であり

$$
C_{n}=5(\mu \mathrm{F})
$$

とすると（4)式故よず(30)式より次式を得る ${ }^{(13)}$ 。

$$
n \omega \Phi_{n}=70.0(\mathrm{~V}), I_{n}=0.532 \text { (A).. }
$$

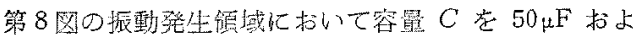
び $20 \mu \mathrm{F}$ とし，電源電Eの振幅 $E$ を变えて主要成分 の周波数り吕1上り小なる振陲の磁束 $\phi_{1}+\phi_{2}$ およひ $\phi_{1}-\phi_{2} \bigcirc$ 周波数成分救めた。笑験結果之解析結果 を定罵的に比較するため，抵抗 $R_{1}$, 容显 $C$, 電源電 压の振幅 $E$ ，磁束 $\phi_{1}+\phi_{2}$ 占よび $\phi_{1}-\phi_{2}$ を(4), (31)

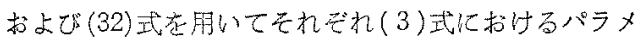

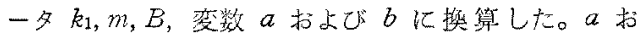
よび bの各周波数成分を䒠测した結果は第 3 章术上 び第 4 章の理馀的考察とよく一致し，たの振動は(10)

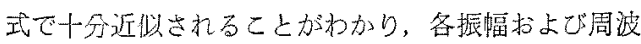
数は第 9 图扰よで第 10 図に示したようになる籍2园

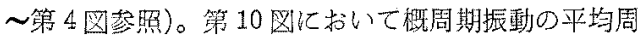

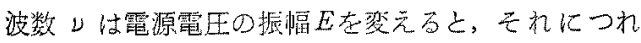
て連続的湾化する。

$a$ と $b$ の結合に関するパラメータ $k_{1}$ 茫変化した場 合に対し，第3章に拈ける解析方法の妥当性を吟昧す るために，抵抗 $R_{1}$ 竞えて概周期症動の周波数特性

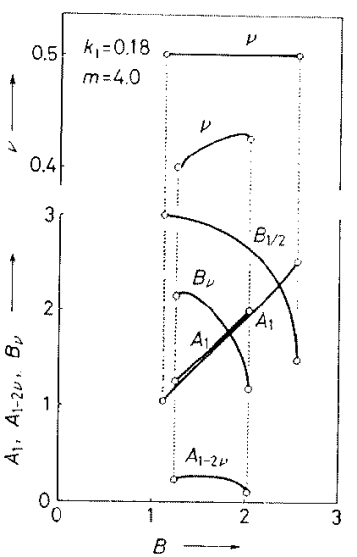

第 10 图 $1 / 2$ 調波振動㧍よび平均 周波数が $1 / 3$ と $1 / 2$ の間の概周期 振敦の振幅特性招よび周洨数特性

Fig. 10. Amplitude characteristic and frequency characteristic of the 1/2-harmonic oscillation and the almost periodic oscillation whose average frequency lies between $1 / 3$ and $1 / 2$.

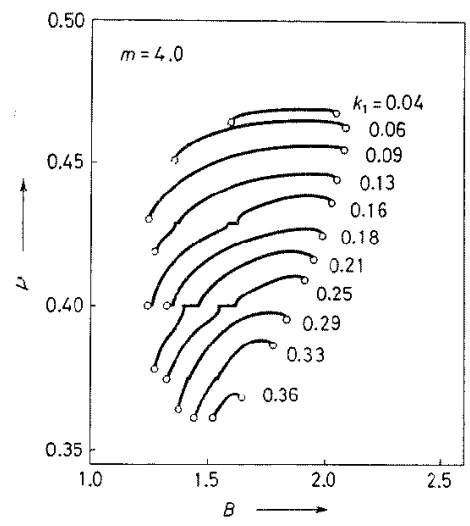

第 11 図平均周波数加 $1 / 3$ < $1 / 20$ 間O 概周期桭勤の周波数特性

Fig. 11. Frequency characteristic of the almost periodic oscillation whose average frequency lies between $1 / 3$ and $1 / 2$.

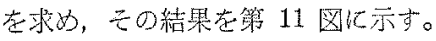

第 11 図志解析で得られた第 5 図と比較すると, 電 源周波数の $3 / 8,2 / 5$ および $3 / 7$ の周波数 $\nu$ を持つ周 期振動方電源電生O振幅 $E$ O 狭い範聿で電源に同期 化することを除いては実験結果と解析結果は定性的に おおむむ致する。パラメーダ $k_{2}$ を変化した場合に 対しても，解析力法の妥当性を確加るるとができ 


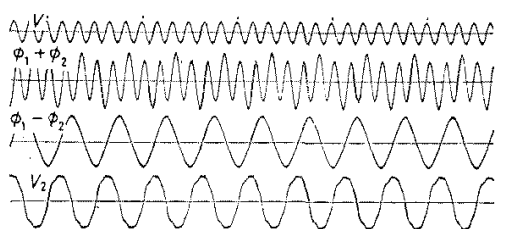

(o) 1/3-harmonic oscillation $(m=10, \theta=1.8)$

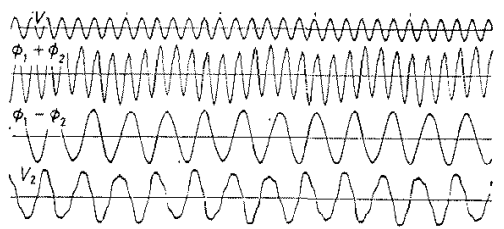

(b) $1 / 3-1 / 2$-harmonic oscillation $(m=4,0, \theta=1.6)$

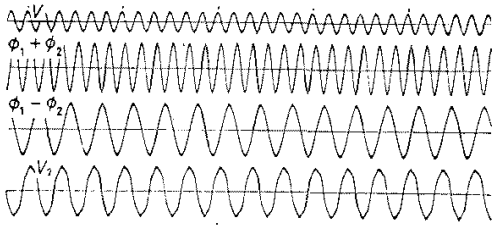

(c) 1/2-harmonic osciltation $(m=4.0, B=1.6)$

第 12 図振動の稵束 $\phi_{1}+\phi_{2}, \phi_{1}-\phi_{2}$, 麗圧

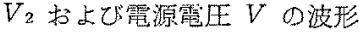

Fig. 12. Waveforms of the oscillations. $V=$ applied voltage, $\phi_{1}+\phi_{2}, \phi_{1}-\phi_{2}=$ oscillating fluxes, $V_{2}=$ terminal voltage across capacitor.

る。定性的にはパラメータ $k_{1}, k_{2}$ が加なり大きくても 計算結果証実験之一致する。特比 $k_{1}, k_{2}$ が 0.2 以下 であれば定量的にすよく一致している。(10)式の程度 の近似では，パラメータの狭い領域に秥いて同期化す る振動を解析することができないが，第3章の解析方 法を用いて更に高次の近似解を求めれば，狭い同期化 領域を持つ周期振動を考察するととができると共に， 定量的にす解析することができると考えられる。

各振動の磁束 $\phi_{1}+\phi_{2}, \phi_{1}-\phi_{2}$, 電压 $V_{2}$ および電源 電王 $V$ の時聞的变化を観察した絬果を第 12 图に示 す。磁束 $\phi_{1}+\phi_{2}, \phi_{1}-\phi_{2}$ 拉よび電圧 $V_{2}$ は, それぞれ $a, b$ 朽上び $d b / d \tau$ に比例する。なお，オシログラム (b)の概周 期振動の平均周波数 レは $0.418 \cdots \cdots$...で る。

\section{7. むすび}

二つの可飽和鉄心を持つ変圧器結合回路に正弦波電 正を印加した場合に発生する非線形振動について考祭 した。振動を記述する方程式は 1 階と 2 階の連立非線 形徽分方程式となる。この方程式の解に含まれる各周
波数成分について一般的に考察した。解の周波数成分 を決定する万法として，まず外力周波数を 1 とすれば， これと固有周波数付近の周波数しの2成分よりなる解 第 1 次近似解上仮定し，乙の後繰返し法によって解 の近似を高力ることにより，始に含まれる周波数成分 定め方方法在提案した。周波数山扎よび各周波数成

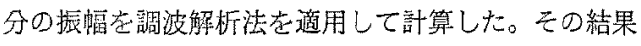
外力周波数之簡篻な有理数比在なす周波数りの成分を 持つ周期解および外力周没数と舆理数比をなす周没数

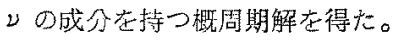

概周期解の平均周波数りは，采のパラメータを变え るとそれにつれて速続的に変化する。また電気回路を

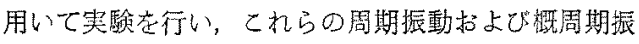
動が美際に発生すること確加めだ。更に周期解沾よ び概周期解の安定性を吟陎した。特に概周期解の振䡒 の安定性范諭じた。

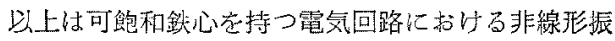

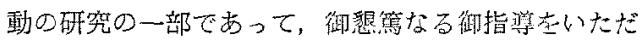

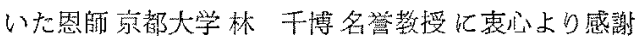
の㸃を表する次第である。

(昭和 50 年 9 月 10 日受付，同 51 年 5 月 28 日再受付)

\section{文献}

(1) E. Goto: Proc. IRE 47, 1304 (1959)

(2) C. Hayashi: Automation and Remoto Control 2, 889 (1961)

(3) C. Hayashi: Nonlinear Oscillations in Physical Systems (1964) McGraw.Hill

(4) 林: 昭18電気学会連大予稿 6

(5) W. T. Thomson: Trans. Amer. Inst. Elect. Engrs 57, 469 (1938)

(6) 林: 三蔆電機 18，10，317 (昭 17)

(7) C. Hayashi: Forced Oscillations in Nonlinear Systems (1953) Nippon Printing and Publishing Co., Ltd., Osaka, Japan

(8) L. N. Robinson: Trans. Amer. Inst. Elect. Engrs 34, Pt. II, 2182 (1915)

(9) K. Heegner: Zeitschrift für Physik 29, 91 (1924)

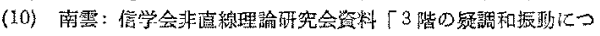
いて」(昭 32-12)

（11）林・上明・大暗・川上: 同上「2つ0可絇和鉄心を有する非 線据回路」(䀡 40-12)

(12) W.J. Cunningham: Introduction to Nonlinear Analysis (1958) McGraw-Hill

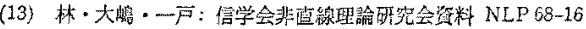
(昭 43-12)

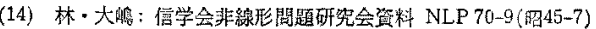

(15) 林·大牌：同上 NLP72-4（昭 47-7）

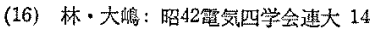

(17) 林. 大暗：昭43同上 32

(18) I. G. Malkin: Some Problems in the Theory of Nonlinear Oscillations (1956) Gostekhizdat, Moscow 